\title{
VIDAS HIPOTECADAS: DA BOLHA IMOBILIÁRIA AO DIREITO À MORADIA
}

\author{
Bruno Pereira Reis* \\ * Universidade Estadual de Campinas, Instituto de Economia, Campinas, SP, Brasil.
}

COLAU, A.; ALEMANY, A. (org.). Vidas hipotecadas: de la burbuja inmobiliaria al derecho a la vivienda. Barcelona: Angle Editorial, 2012.

Organizado por Ada Colau e Adrià Alemany e publicado originalmente em idioma catalão pela Angle Editorial, o livro Vidas hipotecadas: de la burbuja inmobiliaria al derecho a la vivienda (2012) representa um valioso ponto de partida para compreender, à luz da história, as transformações recentes no mercado imobiliário na Espanha.

Os autores relatam, com alto grau de aprofundamento, o conjunto de experiências acumuladas no âmbito da Plataforma dos Afetados pela Hipoteca (PAH), um importante movimento social ligado à questão habitacional no país que ganhou bastante protagonismo nas duas últimas décadas, particularmente no contexto pós-crise. A forma de organização desse movimento, que surgiu em Barcelona, na Catalunha, foi bastante admirada pela população, tanto que seu modo de atuação rapidamente se disseminou pelo território e sua principal liderança, Ada Colau, tornou-se prefeita daquela cidade no ano de 2015. A luta pelo direito à moradia, o apoio jurídico e emocional oferecido às pessoas que perderam suas casas para os bancos e a denúncia das práticas financeiras consentidas pelo Estado espanhol, portanto, são alguns dos aspectos que norteiam essa obra.

O livro está organizado em três partes principais, além de uma introdução feita por Colau e Alemany e dos prólogos escritos por Gerard Pisarello e José Coy².

1. Professor de Direito Constitucional da Universidade Autônoma de Barcelona (UAB).

2. Membro da PAH da Província de Múrcia (Espanha). 
No capítulo 1 são levantadas algumas questões fundamentais para o entendimento da situação da crise espanhola, denominada pelos autores "DNA da bolha imobiliária”. O capítulo 2 trata especificamente da transformação de uma problemática individual em uma luta coletiva; assim, os autores relatam os esforços empreendidos na organização da população no âmbito da PAH. Por fim, o capítulo 3 está apoiado em uma revisão dos aspectos legais que envolvem o processo de execução hipotecária no país; por essa razão, as pautas e os conselhos que foram registrados nessa parte servem também como um "guia” para auxiliar as vítimas desse frauduloso processo que alimenta a riqueza de entidades financeiras.

Os autores realizam uma sólida análise do DNA da bolha imobiliária espanhola e apontam que o direito à moradia (artigo 47 da Constituição espanhola) foi sistematicamente violado ao longo do tempo, contexto em que o poder público se tornou cúmplice desse processo ao apostar em um modelo de crescimento econômico fácil, rápido e de curto prazo, apoiado, sobretudo, na liberalização da urbanização (Lei de Solos de 1998) e do crédito hipotecário. Em outras palavras, em uma conjuntura econômica de alta liquidez, viabilizada pelo aumento paulatino dos investimentos estrangeiros diretos (IED) na Espanha, no contexto de sua entrada na União Europeia (UE), adotou-se uma política urbana que impulsionou a mercantilização da moradia e o regime de propriedade, o que promoveu um ciclo imobiliário sem precedentes no país.

Mas os autores destacam que compreender o projeto proprietarista espanhol requer considerar os aspectos históricos, em especial as políticas habitacionais adotadas durante o franquismo ${ }^{3}$, pois foi nesse período que a produção imobiliária se consolidou como um setor dinamizador da economia nacional, além de funcionar como um importante mecanismo de controle social. Durante o período de transição democrática no país, o que se verificou foi uma continuidade e um reforço desse projeto, ao passo que a economia espanhola se consolidava de maneira mais efetiva nos circuitos globais de reprodução do capital.

Em um contexto em que a ideologia neoliberal ganha força em âmbito mundial, a liberalização dos fluxos financeiros vai reorganizar a economia política dos diferentes países. Na Espanha, a partir de 1960, verifica-se uma paulatina retração do Estado no provimento de bens e serviços básicos para a população, que se acentua nas décadas seguintes e "aniquila” grande parte dos instrumentos de intervenção pública. A partir daí, apontam os autores, o Estado tornou-se uma "correia de transmissão" dos interesses privados.

3. Regime político ditatorial que vigorou na Espanha entre os anos de 1939 e 1975, marcando a vitória de um grupo nacionalista que colocou no poder o general Francisco Franco. 
Neste sentido, a entrada da Espanha na União Europeia (UE) e, consequentemente, a substituição de sua antiga moeda - peseta - pelo euro conduziram o país a um novo papel na divisão internacional do trabalho (REIS, 2019). Verifica-se, então, um aprofundamento na implementação de políticas que buscaram, mais do que nunca, atender aos interesses privados nacionais e internacionais. Como já mencionado, a flexibilização da legislação urbana e de crédito seria responsável por alçar as dinâmicas imobiliárias a um novo patamar, o que fez com que o mercado imobiliário se configurasse como um espaço econômico privilegiado de valorização dos capitais que agem sobre o ambiente construído.

A “economia do tijolo”, como ficou conhecida em seu momento áureo, representava cerca de $30 \%$ do PIB nacional (considerando as atividades indiretas que se articulam ao setor). Estima-se que, entre os anos de 1998 e 2007, foram produzidas, aproximadamente, 6,6 milhões de novas moradias, o que fez com que $87 \%$ da população espanhola se tornasse proprietária; esses números são superiores à média europeia, que gira em torno de $60 \%$. Nesse contexto, toda e qualquer possibilidade de implementação de uma política urbana apoiada no regime de aluguel havia sido descartada. A reforma da Lei de Arrendamentos de Urbanos ${ }^{4}$, por exemplo, tornou o aluguel uma opção instável, cara e precária, destacam os autores.

Colau e Alemany chamam a atenção para a relação entre o processo de formação da bolha imobiliária espanhola e os discursos que foram disseminados publicamente por supostos pesquisadores especialistas, consultores profissionais, representantes do setor imobiliário, políticos e até mesmo presidentes de bancos, que em debates televisionados defendiam seus interesses apoiados pelo lobby de empresas imobiliárias, construindo um imaginário popular que sobrepunha o valor de troca da moradia em detrimento de seu valor de uso. Esses agentes, portanto, reforçavam a ideia de que a hipoteca era um ativo financeiro seguro, sinônimo de status social e êxito profissional, enquanto o aluguel era sinônimo de fracasso pessoal e de inferioridade social.

A partir daí, o fenômeno da especulação imobiliária ganhou força, o que nos ajuda a entender o processo de elevação constante dos patamares de preços imobiliários e fundiários desse período. De acordo com os dados obtidos, cerca de $40 \%$ do total dos imóveis eram destinados à chamada "demanda especulativa”, o que contradiz o modelo econômico de concorrência perfeita, o qual pressupõe a constituição de um preço de equilíbrio. No mercado imobiliário, como se sabe, as coisas são bastante diferentes ou mesmo imperfeitas, sobretudo porque o padrão de concorrência oligopolizado desse mercado - com poucos produtores e muitos

4. Também chamado "Decreto Boyer" em alguns textos sobre o assunto. 
consumidores - configura uma realidade em que os primeiros exercem uma posição de força no processo de formação de preços, causando, assim, o endividamento, um dos traços marcantes do processo de formação da bolha imobiliária espanhola.

No âmbito da administração pública, os autores enfatizam as consequências nocivas que o processo de privatização do Banco Espanhol (que se iniciou em 1980) trouxe para milhares de cidadãos do país. À medida que passaram a gerenciar a poupança das famílias, os bancos privados também detiveram o poder de escolher os projetos que iriam financiar, determinando, assim, a estrutura produtiva do país, que se tornou menos diversificada ao longo dos anos. Isso significa que boa parte das poupanças foi parar diretamente no mercado imobiliário, tido como a "galinha dos ovos de ouro" daquele período, especialmente por ser mais dinâmico e por apresentar os maiores rendimentos naquele contexto. Mas esse também seria o grande erro, apontam os autores, já que "colocar todos os ovos na mesma cesta" acarretaria efeitos catastróficos, no momento em que se instaurava a crise financeira internacional. Fuga de capitais, diminuição da liquidez e do acesso ao crédito, ampliação do desemprego e do grau de inadimplência, que, por sua vez, gerou uma enorme onda de despejos, são alguns dos exemplos que ajudam a entender os efeitos da crise na Espanha a partir de 2008.

Os autores também reconhecem a (ir)responsabilidade das entidades financeiras nesse processo, pois foram elas que desenvolveram um perverso sistema de incentivos que premiava aqueles promotores que vendessem o maior número de hipotecas, além de terem concedido milhares de empréstimos sem avaliação adequada, endividando, desse modo, milhares de trabalhadores cujos rendimentos eram insuficientes para pagar o montante emprestado.

De maneira bastante contraditória, o Estado, que deveria amparar esses trabalhadores, efetuou ajudas públicas e injetou dinheiro nesses bancos, endividando-se em função da lógica perversa da acumulação financeira. A reforma financeira realizada ${ }^{5}$ serviu apenas como instrumento para dissipar a desconfiança do sistema financeiro espanhol e tentar "reanimar" o mercado imobiliário, sem resolver efetivamente os problemas sociais, econômicos e urbanos da população afetada pela crise.

Em um contexto fortemente marcado por injustiças sociais e urbanas, ganhou força uma resposta coletiva para o caos gerado pelo estouro da bolha imobiliária: a consolidação da PAH, assunto discutido pelos autores no segundo capítulo do livro.

5. Essa reforma exigia a criação de um "Banco Ruim” ("banco malo" em espanhol), que comprou os ativos imobiliários considerados “tóxicos” para revendê-los posteriormente. 
Colau e Alemany apontam que antes havia na Espanha um movimento social de luta por moradia com o nome $\mathrm{V}$ de Vivienda, mas, com a instauração da crise internacional, um novo ponto de inflexão exigiu possibilidades renovadas de organização e intervenção. Assim, a PAH e o V de Vivienda se uniram para repensar o acesso à moradia, em meio à enorme onda de despejos que ocorria em diferentes lugares do país.

O primeiro passo foi aceitar a tese de que se tratava de um problema coletivo, de ordem estrutural. Por essa razão, tornou-se necessário colocar em marcha um processo de desculpabilização das vítimas para o respectivo empoderamento, ou seja, o movimento buscou, a todo o momento, construir um espaço de suporte mútuo e de solidariedade que sobrepunha o bem comum ao individual. O que se buscou foi dar respostas concretas e imediatas às famílias que não podiam esperar por mudanças legislativas.

A forma de organização era horizontal e a estratégia estava apoiada no assessoramento coletivo, que tratava de casos particulares em assembleias coletivas e que, com o passar do tempo, se tornou uma ferramenta imprescindível e transformadora, ao capacitar o indivíduo técnica e emocionalmente, convertendo-o em um sujeito ativo e transmissor de conhecimento, capaz de assessorar outras pessoas necessitadas que estavam vivenciando a mesma situação.

Com os novos recursos da web e as redes sociais, o movimento ganhou força e se expandiu continuamente, o que permitiu que pessoas de diferentes regiões do país entrassem em contato e trocassem experiências, além de compartilhar estratégias de atuação na escala local.

A multiplicação da PAH converteu a questão habitacional em pauta de agenda política nacional - a campanha "Stop Desahucios!" -, exigindo respostas imediatas por parte do governo em suas diferentes escalas (local, autonômica e central). Grosso modo, podemos destacar os três principais objetivos desse movimento social: i) a dación en pago ${ }^{6}$; ii) a paralisação dos despejos; iii) a conversão das moradias hipotecadas em um parque público de moradias de aluguel social. Somente a partir do cumprimento desses objetivos seria possível alterar a correlação de forças estabelecida na sociedade, dado que a legislação espanhola protege firmemente as entidades financeiras.

No âmbito das administrações locais, um problema recorrente era a falta de instrumentos jurídicos e de recursos financeiros, visto que os cofres municipais

6. Optamos por manter o termo original porque não encontramos uma tradução equivalente para o português, mas se trata da possibilidade de quitar uma dívida hipotecária com o banco por meios legais, mediante a entrega do imóvel (semelhante ao que no Brasil se denomina alienação fiduciária). 
também sofriam fortemente com a crise instaurada, num contexto de aumento da demanda por serviços sociais. Nesse sentido, a PAH realizou, em dezembro de 2010, uma campanha dirigida a todos os governos locais para se posicionarem publicamente diante do governo central, com o propósito de reformular a legislação hipotecária do país. No período de um ano, cerca de duzentos municípios aprovaram a moção, entretanto os autores relatam que boa parte dos governos priorizou medidas que não gerassem conflitos com os bancos, dentre as quais sobressaem o fornecimento de uma ajuda mínima, que não resolvia o problema das famílias afetadas, e uma restrição dos critérios para o sorteio dos imóveis. No âmbito das Comunidades Autônomas, o destaque foi a Catalunha, que, em virtude da grande mobilização popular, construiu um modelo de intervenção que acabou sendo "exportado” para as demais comunidades autônomas espanholas.

Colau e Alemany apontam que essas "pequenas grandes vitórias", tanto simbólicas quanto concretas, fortaleceram o movimento e o tornaram mais articulado, ou seja, com a realização de um sólido diagnóstico sobre a crise e a elaboração de propostas sérias, viáveis e necessárias, os bancos mostraram-se mais dispostos a negociar, o que evidencia o poder de organização da população em prol de uma causa coletiva, no caso, a questão habitacional.

A capacidade de construir, passo a passo, novas formas de alterar as "regras do jogo" possibilitou o vislumbre de uma mudança no modelo de desenvolvimento econômico, tendo em vista que, a partir daí, o debate popular concentrou-se em conceber maneiras de romper com o processo de financeirização da habitação que havia se consolidado.

No caminho oposto, as administrações públicas insistiram na manutenção da ordem vigente, injetando dinheiro público nas mesmas empresas responsáveis por quebrar o país, fato que legitima e induz a pensar novas formas de planejamento regional e urbano que contemplem o tratamento da habitação como bem comum.

Do ponto de vista dos aspectos legais, tema amplamente discutido no terceiro capítulo do livro, os autores apontam a existência de dois importantes modelos consolidados na literatura: i) o modelo anglo-saxão; ii) o modelo de reabilitação. $\mathrm{O}$ primeiro permite que o devedor tenha um novo recomeço (fresh start), enquanto o segundo, mais comum nos países europeus e também aplicado na Espanha, favorece os bancos, pois trata a hipoteca como um empréstimo pessoal em que o imóvel é apenas uma garantia em caso de não pagamento. Desse modo, ainda que o imóvel seja entregue para o banco, continuam a correr juros sobre a dívida, até que seja realizado um acordo.

Os dados estatísticos apontam que, entre 2007 e 2011, foram produzidas cerca de 349.438 ordens de execução hipotecária na Espanha. Ante esses números, a PAH 
questiona não apenas a falta de mecanismos institucionais para amparar as vítimas desse processo, mas também a natureza perversa do modelo de desenvolvimento econômico adotado, que se apoia, sobretudo, na hegemonia das finanças que busca novos horizontes para se reproduzir - neste caso, mediante as dinâmicas econômicas ligadas ao imobiliário e ao fundiário.

Em suma, o livro organizado por Colau e Alemany, além de reunir um conjunto de informações empíricas detalhadas e sistematizadas, propõe ao leitor pensar a realidade com base em um tripé analítico que articula economia, sociedade e território, apoiado, sobretudo, em um viés político anti-hegemônico, horizontal e cooperativo. O livro trata, ainda, de uma problemática extremamente importante no período atual, em que o mercado imobiliário assume grande protagonismo na produção do espaço em diferentes lugares no mundo. Neste sentido, ainda que a obra aborde uma realidade europeia, seu legado nos faz refletir sobre o modo pelo qual esses processos se manifestam e se materializam na periferia do capitalismo.

\section{Referências}

COLAU, A.; ALEMANY, A. (org.). Vidas hipotecadas: de la burbuja inmobiliaria al derecho a la vivienda. Barcelona: Angle Editorial, 2012.

REIS, B. P. Transformações recentes no mercado imobiliário na Espanha: auge e crise da produção habitacional sob ritmo das finanças. 2019. Dissertação (Mestrado em Desenvolvimento Econômico) - Instituto de Economia da Unicamp, Campinas, 2019. 


\section{Bruno Pereira Reis}

Professor de Geografia na Escola Técnica Estadual Conselheiro Antônio Prado (Etecap) em Campinas (SP) desde 2018. Concluiu sua graduação em Geografia pela Faculdade de Ciências e Tecnologia da Universidade Estadual Paulista (FCT/Unesp) no ano de 2016 e o mestrado em Desenvolvimento Econômico junto ao Instituto de Economia da Universidade Estadual de Campinas (IE/Unicamp) em 2019. Foi bolsista Fapesp entre os anos de 2013 e 2015 e do CNPq entre 2016 e 2018. Em ambas as oportunidades, realizou estágio de pesquisa no exterior junto à Universitat de Lleida, na Catalunha, Espanha. Atualmente, desenvolve pesquisa nas áreas de Geografia Humana e Desenvolvimento Econômico, com foco no processo de produção do espaço, nas dinâmicas do mercado imobiliário, na questão habitacional e no processo de financeirização do capitalismo.

Email: brunop.reis01@gmail.com

ORCID: 0000-0002-2604-1615

Submissão: 8 de maio de 2020.

Aprovação: 30 de junho de 2020.

Como citar: REIS, B. P. Vidas hipotecadas: da bolha imobiliária ao direito à moradia. Revista brasileira de estudos urbanos e regionais. V.22, E202022, 2020. DOI 10.22296/23171529.rbeur.202022

Artigo licenciado sob Licença Creative Commons CC BY-NC 4.0. https://creativecommons.org/licenses/by-nc/4.o/deed.pt_BR 